\title{
Does noise shift or delete spikes?
}

\author{
Sergej Voronenko ${ }^{1 *}$, Benjamin Lindner ${ }^{1,2}$ \\ From Twenty Second Annual Computational Neuroscience Meeting: CNS*2013 \\ Paris, France. 13-18 July 2013
}

Stochastic leaky integrate-and-fire neurons are widely used to study properties of neural networks (e.g. [1]) as well as the spontaneous activity [2] and signal transmission [3] of single neurons. They have also been employed in studies of the 'common-noise' problem, i.e. the question of how correlated input to two cells causes output spike train correlations of these neurons [4].

In the cortex, input correlations seem to be weak [5] (in terms of the above sketch, $\mathrm{c}<<1$ ), however, in the sensory periphery with a strong time-dependent stimulus the situation can be completely different (e.g.[6]). The two neurons receive the same strong stimulus (often modeled as a random signal) and each neuron is subject to a small amount of intrinsic noise $(1-\mathrm{c}<<1)$. Without the intrinsic noise two identical neurons would fire in complete synchrony. How does the weak noise change the spikes?

To address this question, we first study two versions of inhomogeneous Poisson processes. In one version the intrinsic noise can shift spike times, in the other the noise leads to deletions and additions of spikes. We construct these processes in such a way that the correlations between the modulated spike trains and the perturbing noise is the same in both versions. In this setup, it is possible to analytically calculate the cross-correlation between two spike trains with independent intrinsic noise. By comparison with extensive simulations of stochastic integrate-and-fire neurons we then inspect, which of the two modulation methods is more appropriate to capture the effect of a weak noise on the spike train of a dynamic neuron model.

\section{Acknowledgements}

This work was funded by the BMBF (FKZ: 01GQ1001A).

\section{Author details}

${ }^{1}$ Department of Physics, Humboldt-Universität zu Berlin, Berlin, 12489, Germany. ${ }^{2}$ Bernstein Center for Computational Neuroscience, Berlin, 10115, Germany.

Published: 8 July 2013

\section{References}

1. Brunel N: Dynamics of sparsely connected networks of excitatory and inhibitory spiking neurons. J Comput Neurosci 2000, 8(3):183-208.

2. Burkitt $A \mathrm{~N}: \mathrm{A}$ review of the integrate-and-fire neuron model: I. Homogeneous synaptic input. Biological cybernetics 2006, 95(1):1-193.

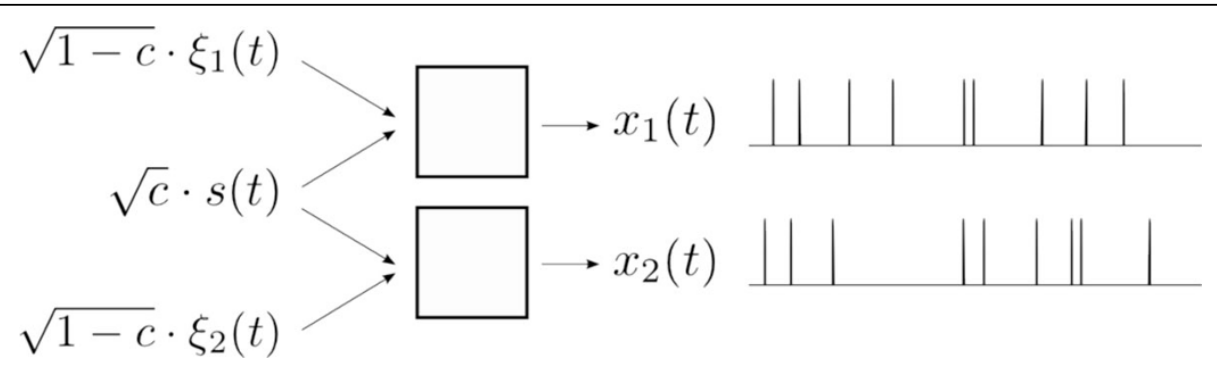

Figure 1 Two neurons receive a common signal and distinct intrinsic noise. $\mathrm{c}$ is the correlation parameter that tunes the strength of the input correlation.

\footnotetext{
* Correspondence: sergej@physik.hu-berlin.de

'Department of Physics, Humboldt-Universität zu Berlin, Berlin, 12489,

Germany

Full list of author information is available at the end of the article
}

\section{C) Biomed Central}

(c) 2013 Voronenko and Lindner; licensee BioMed Central Ltd. This is an Open Access article distributed under the terms of the Creative Commons Attribution License (http://creativecommons.org/licenses/by/2.0), which permits unrestricted use, distribution, and reproduction in any medium, provided the original work is properly cited. 
3. Burkitt AN: A review of the integrate-and-fire neuron model: II. Inhomogeneous synaptic input and network properties. Biological cybernetics 2006, 95(2):97-112.

4. De la Rocha J, Doiron B, Shea-Brown E, Josic ' K, Reyes A: Correlation between neural spike trains increases with firing rate. Nature 2007, 448:802-8065.

5. Zohary, Ehud, Michael N, Shadlen, William T, Newsome : Correlated neuronal discharge rate and its implications for psychophysical performance. Nature 1994, 140-143.

6. Alonso JM, Usrey WM, Reid RC: Precisely correlated firing in cells of the lateral geniculate nucleus. Nature 1996, 383(6603):815-819.

doi:10.1186/1471-2202-14-S1-P246

Cite this article as: Voronenko and Lindner: Does noise shift or delete spikes? BMC Neuroscience 2013 14(Suppl 1):P246.

Submit your next manuscript to BioMed Central and take full advantage of:

- Convenient online submission

- Thorough peer review

- No space constraints or color figure charges

- Immediate publication on acceptance

- Inclusion in PubMed, CAS, Scopus and Google Scholar

- Research which is freely available for redistribution

Submit your manuscript at www.biomedcentral.com/submit

C) Biomed Central 